Silius Italicus

Solinus

Statius

Suetonius

Symmachus

Terence

Theognis

Theophylactus Simocatta

Valerius, Julius

Valerius Flaccus

Vegetius

Vibius Sequester

Victor, Sex. Aurelius

Zonaras

Zosimus
Adversus Pyrrhonem

Punica

Collectanea rerum memorabilium

Silvae

De vita Caesarum

Epistulae

Comoediae

Elegiae

Historiae

De rebus gestis Alexandri Magni

Argonauticon

Epitoma rei militaris

Geographical glossary

Epitome de Caesaribus

Epitome Historiarum

Historia Nova
288-290

291

292

410-412

293-295

296-297

298

299-300

301

142

$302 s$

16

303

304-313

314-315

\title{
ClASSICAL CIVILISATION AT THE UNIVERSITY OF NATAL,
}

\section{PIETERMARITZBURG}

At the University of Natal in Pietermaritzburg, Classical Civilisation has been a two-year major in the Faculties of Arts and Social Science for almost 25 years. During this period the subject has gone through three significant periods which I shall outline in the course of this paper, highlighting successes and failures and hopefully indicating which direction the subject should be taking, as we chart the unknown waters of university education in the South Africa of the future.

The first phase of Classical Civilisation at UNP I shall call "Oxbridge in the colonies". The staff, entirely Oxbridge trained, believed that Classical Civilisation was a bogus academic discipline for dilettantish students who fancied careers as Sandton hostesses, or that it was a pleasant pastime for lavender-haired old ladies who went to Italy during the summer vacation and produced elegant water colours of Roman ruins with captions like "Lavinia and I contemplate the transience of mortal things". The course was divided into three sections - literature, philosophy and ancient history, and was dominated by vast chunks of the latter. This was regarded as the scholarly component of the course: the narrative was assumed to be read; ancient history meant problems in the source material and hours were devoted to the pedantic minutiae of conspiracies ... Catiline, Primus and Murena, and the agrarian laws for light relief. There were constant moans from the staff about teaching literature or philosophy (in particular the Pre-socratics and Plato) in translation: the translations were inadequate or misleading, the class had no Greek or Latin, and much time was spent in giving the students the actual transliterated Greek or the Latin which appeared in garbled glory in examinations. The only rejoicing occurred when one of these students decided to enrol for a course in Greek or Latin - then Classical Civilisation was seen to have had some real purpose. If, armed with one year of Latin and one year of Greek, they went on to read for an honours degree in Classical Civilisation,

Retyping of translation by Lieutenant John Clarke (1767). 
the course was made impossibly demanding - six papers, two full projects, Greek and Latin if they were not competent enough in both and an essay a week. Consequently, very few students ever progressed this far - three or four (to my knowledge) in a ten-year period. There was no direct teaching of society or religion or archaeology or art, unless the box of slides we discovered (featuring crinolined ladies posing arnongst the remains of Pompeii) indicated an elegant gesture in that direction.

The second phase of Classical Civilisation at UNP I shall call "Oxbridge goes native". This was the discovery in the late seventies and early eighties that Classical Civilisation could be a departmental growth point - a potential money spinner - if presented attractively and appropriately for South African English-speaking undergraduates who were not really embryonic British gentlefolk after all. We were beginning to discover that we were in Africa (that dark and forbidding continent), despite the imperial buildings and the imperious statue of Queen Victoria which dominated the city centre. Classical Civilisation was radically overhauled and divided into a series of themes or topics, each of which had 15 lectures devoted to it. Art was imported on a grand scale; women, slaves and blacks were discovered. The full course appeared as follows:

In the first year, ten topics were offered:

Greek vase painting
Greek and Roman architecture
Greek History
Greek Philosophy
Mythology

In the second year:

Greek and Roman Epic
Greek and Roman Religion and Philosophy
Greek Tragedy
Roman History
and the Special Topics section:
Women in Antiquity
Slavery in the Greco-Roman world

Greek sculpture

Epic (Homeric)

Roman History

Greek Tragedy

Roman Love Elegy

\author{
Greek Comedy \\ Roman Satire: \\ Greek History \\ Greek and Roman Lyric Poetry
}

Blacks in Antiquity

There were, of course, many omissions, but, on the whole, the course worked rather well and our numbers more than doubled - to 75 in Classical Civilisation. I and 23 in Classical Civilisation II in 1989. We were, however, unhappy with the course: because of sabbatical leave, the topics were constantly being shuffled around and many anomalies arose. For example, Roman Love Elegy could be the first literature taught in Classical Civilisation I (before the mythology package and before any notion of Hellenistic literature); Roman history could be taught before Greek, and so on. This wreaked havoc with some students' rather hazy sense of chronology, but there was a more important problem; we felt that we had balkanised the ancient world to such an extent that it had ceased to have meaning, as a cultural totality, for a student enrolling for what was after all an introduction to the ancient world. Contextualisation was the intellectual parrot-cry in other academic disciplines, and we felt that we too had to look more carefully at the full cultural context in which a work of art or literature (for example) was produced.

This brings me to the third phase of Classical Civilisation at UNP, which I shall call "the Afro-American experiment". During the years of phase two, the university underwent a number of important changes which necessarily affected Classical Civilisation: the staff changed, the student body changed from being all white to one which is now more than one-third black, and the Arts Faculty semesterised its courses. Consequently, we have tried 
to mount a Classical Civilisation course which is far more flexible and wide-ranging than previous courses.

In our present course, the first year, divided into two semesters, is entirely Greek: the second year, also divided into two semesters, is entirely Roman. For a major in the subject, the two Greek semesters (the Bronze Age and Archaic Greece, Classical Athens), the two Roman semesters (from the Etruscans to the Republic, the Roman Empire) and two semesters of special topics have to be completed in two or three years, depending on the structure of the student's curriculum and his/her abilities. There are no strict pre-requisites for entry to any segments of the course: if a student wants to be exposed to the Romans only, she can enrol for the Roman semesters; if a theological student wants to explore the gutters of the Roman Empire, he can sign up for the semester on the Empire; student refugees from the English department, for example, can readily enrol for the special topics in "Gender and Sexuality in Antiquity" or "Greek, Roman and African rituals" without necessarily completing either the Greek or the Roman semesters. However, an intending major is urged to follow the course in its chronologically arranged sequence, so that full benefit from the holistic arrangement of material can be obtained.

This is the major change which has occurred. We have decided to adopt an holistic approach to the teaching of a culture: consequently, history flows into art, literature, music, medicine, social and sexual mores, philosophy, magic and religion, and so on.

The Classical Civilisation course is now in its third year, and, judging from the response to our course evaluation forms, is going down well: there are still problems with superficiality which a cultural Cook's tour of this nature always brings, but our desire to emphasise the context and totality of the culture has produced some excellent, intelligent work, both in essays and in exams. The special topics (Myth, Comparative Greek, Roman and African ritual, Gender and Sexuality in Antiquity and Greek Drama) seem to be particularly successful, and this has suggested a desire to balkanise again and market those nuggets of the ancient world which we see are successful. There is no doubt in my mind that Classical Civilisation has a crucially important role to play in the survival of the classics in South Africa. We have to generate a culture of interest in our subject which transcends the narrow focus of our courses in the past. We do not yet have enough black students in our Classical Civilisation courses. A steady trickle of Indian students, a mere handful of African students. At the beginning of each academic year, I speak to the newly enrolled black students on campus about the classics ... I usually do this by talking about African ritual, and then lead in to a discussion of a particularly "African" Greek rite such as sacrifice or something to do with the fertility of the crop, like the Thesmophoria. There is always enormous interest, but the students do not enrol for the Classical Civilisation course which is still too white for a university more than one-third black. This is the issue which we need to address. Classical Civilisation seems to thrive in other parts of Africa at the universities of Malawi, Zimbabwe, Cape Coast in Ghana, Ibadan in Nigeria, for example. At Cape Coast, two Classical Civilisation courses (Greek Drama and Greek Democracy) are offered in the first foundation year to students from all faculties. They have proved so popular that the Classics Department there has had to turn students away. I suspect that when we come to our senses and introduce a four year undergraduate degree (most of our students take four years to complete three year degrees anyway), with a foundation year on the Ghanaian model for all our students, we will be able to ensure that Classical Civilisation has a role to play in the foundation year where interest in the classics can be stimulated and nurtured. We really do have to say goodbye to what I have called the "Oxbridge in the colonies phase": it was a phase of dry and sterile pedantry which did the cause of classics in this country untold damage. But what about standards, you may cry? What about standards indeed? I have lived through all three phases at our university and I 
can honestly say that if pedantry and unimaginative teaching are synonymous with high standards, then the very notion of standards has to be examined very carefully. Our standards have changed; they have not been lowered. I do think that our department, our students, and the cause of classics are the better for it.

M. Lambert

\section{LATIN PEN FRIENDS:}

\section{Inscriptio ad Commercium Epistularum Latinum}

Teachers and their pupils who wish to correspond internationally in Latin are invited to apply for membership of the international club: Septimanae Latinae Europaeae s.i., c/o Robert Maier, Dresdener Strasse 10, W-6070, Langen, Germany.

\section{"Praat Latyn - Kook in Latyn" \\ Latyn as Internasionale Taal}

Van 22 tot 28 Augustus 1993 word 'n gesellige Latynweek beplan in die pragtige klein Duitse dorpie van Amőneberg naby Marburg/Oberhessen. Vir 330.-DM kry afgevaardigdes verblyf, gesprekke in Latyn en Romeinse kos. Speletjies en ander Romeinse vermaak, asook 'n ekskursie sal geniet word. Die geheel word afgerond met twee Romeinse cenae. Navrae kan gerig word aan Robert Maier, Dresdener Strasse 10, D-W6070 Langen, Duitsland, of tel.: 0049-69-643-53036.

\section{Romulus and Remus on the Rand - The Lupi of Linksfield and Park View}

In the recent Certamen Latinum (the Latin Olympiad) pupils of the two King David High Schools in Johannesburg fared exceptionally well. Of the six finalists two were from the school in Linksfield, and one from the other King David High in Park View.

Akroterion understands that the two schools' principals are brothers, surnamed, appropriately, Wolf. We have not discovered whether, since their pupils' Latin triumph, the gentlemen will be known as Romulus and Remus.

The results of the Olympiad will be published in the next edition of Akroterion.

\section{Unusquisque lingua sua}

The famous Bodleian library in Oxford may be used by visitors who show a proper letter of introduction. When a visitor's bona fides have been accepted, he or she states under solemn oath that he or she will undertake to abide by the rules of the library, particularly not to introduce "flames" into the stacks. 